\title{
Geotouristic trail in the Senhor da Boa Sentença Cemetery, João Pessoa, State of Paraíba (PB), Northeastern Brazil
}

\author{
Luciano Schaefer Pereira ${ }^{1}$ (D) - Marcos Antônio Leite do Nascimento ${ }^{2} \cdot$ Virgínio Mantesso-Neto ${ }^{1,2}$
}

Received: 5 April 2018 / Accepted: 10 April 2019 / Published online: 2 May 2019

(C) The European Association for Conservation of the Geological Heritage 2019

\begin{abstract}
The inclusion of elements of the natural landscape, particularly abiotic heritage, and cultural heritage, to touristic activity as a result of a more demanding market ultimately provides the rise of geotourism, an integrated activity between geosciences, culture, and history of the place in which they operate. The cemeterial tourism is a part of the urban geotourism now rising in Brazil, wherein observation and analysis of the esthetics and of the georesources used in tombs make many tourists and scholars start to patronize this new touristic niche. Thus, this paper proposes a geotouristic trail in Senhor da Boa Sentença Cemetery, the oldest at the Paraiba capital, northeastern Brazil, inaugurated in 1856, by mapping the stone materials used in the gravestones, which serve as tools for sociological, architectural, and geosciences studies. Thirteen different types of granites, as well as other types of rocks, have been identified, as well as various architectural styles; the trail can thus be used both by geotourists and scholars from various fields, being the cemetery an open-air museum.
\end{abstract}

Keywords Geotouristic trail $\cdot$ Cemeterial geotourism $\cdot$ Geodiversity $\cdot$ Stone materials $\cdot$ Senhor da Boa Sentença cemetery

\section{Introduction}

The presence of values associated to material or immaterial goods which can be seen in cemeteries make them a reflection of the society to which they belong. As a rule, these holy fields which normally host a spectacular array of sculptures, monuments, and works of art, besides the tombs of important people from various areas of activities, end up attracting basically people interested in specific fields of knowledge, such as arts and history; the stone material utilized in graves, tombs, and monuments, which present considerable potential for other

Luciano Schaefer Pereira

1schaefer2@gmail.com

Marcos Antônio Leite do Nascimento

marcos@geologia.ufrn.br

Virgínio Mantesso-Neto

virginio@uol.com.br

1 Department of Geography, Faculty of Humanities, University of Coimbra, Colégio de S. Jerónimo, 3004-530 Coimbra, Portugal

2 Department of Geology, University of Rio Grande do Norte, Avenida Salgado Filho, S/N, Bairro Lagoa Nova, Campus Universitário, Natal 1678, Brazil types of study, such as Sociology, Architecture, among others, usually occupies a secondary position, or is plainly left aside.

Cemeterial tourism is a common activity, particularly in Europe, where such programs have been in use for many years, emphasizing local cultural aspects. In Brazil, up until now, this is a very limited activity, occurring only in a few cemeteries in the southern and southeastern region, in capital cities like São Paulo, Curitiba and Rio de Janeiro (Kuzmickas and Del Lama 2012, 2015; Liccardo and Grassi, 2014), and in some specific areas where cultural history is valued, usually triggered by the presence of a high number of descendants of European immigrants.

The definition of geotourism as "the tourism which sustains and enhances the identity of a territory, taking into consideration its geology, environment, culture, aesthetics, heritage and the well-being of its residents (AROUCA DECLARATION 2011)" makes the Senhor da Boa Sentença Cemetery (from here onwards simply SBCS) the ideal place for a cemeterial geotouristic trail. In effect, its material assets, like the rocks and the architectonic elements, as well as its high historical and social meaning, make it a very good subject for the study of (geo)knowledge and culture.

Encompassing both academic and touristic aspects, the SBCS, the largest cemetery in the state of Paraíba, is an open-air museum, allowing the development of studies in a 
number of fields, such as architecture, geology, archeology, and history. It is a museum of petrography, in which researchers and students can find a large variety of rock types, both national and foreign; a museum of different architectural styles; a museum of applied sociology, in which some aspects of the local society in different periods in time can be assessed by the characteristics of the tombs and mausoleums, as well as by the rock material in them utilized.

The cultural identity of the society of Paraíba state in more than a century and a half can be seen reflected in each tomb, each detail, each decorative ornament, in each rock used in the cemetery. The identification and a proper development of the geotouristic potential of the SBSC can therefore bring the development of the research, the education, and even the economy, in that context of the cultural heritage and geoheritage.

Despite its potential, SBSC has never been the subject of a study that could assess its value as a historical, architectural, sociological, and, now, geoheritage attraction. Under those circumstances, of course, a geotouristic trail could never have been developed. In fact, in João Pessoa, there have been few initiatives of urban geotourism (for example, Pereira and Amaral 2014). This paper is the first contribution towards an effort to leverage the potential of the cemetery to start the development of this new field of cultural, scientific, and economic activity.

\section{Methodology}

To reach the desired results, this project was divided in the following phases:

1. Field work: this first phase was dedicated to gathering data, like identifying various rock types used in tombs and mausoleums, the artistic characteristics of various items like sculptures and stone carving works, and the identification of the various architectonic styles and the location of the tombs of important persons. Particular attention was paid to the attempt of interconnecting these various elements.

2. Preparation of thin sections: the petrographic analyses of the thin sections were done using a Leica DMLP petrographic microscope with attached electronic point counter, controlled via computer using Conwy Valley System Ltd.'s PETROG v. 2.45 software. Ten thin sections were prepared of rock types used as tombstones whose samples could be obtained in rock fragments accumulated in the cemetery itself or in nearby dimension stone suppliers. The stones used were classified according to specialized catalogs (like IPT 1990 and the atlas available online on the site of CPRM-Serviço Geológico do BrasilBrazilian Geological Service), which, given the relatively small number of dimension stones available in the market until some decades ago, also allow a tentative location to be considered as the possible origin for some of them. These analyses aimed at recognizing the different rocks' mineralogy, textures, and petrographic classification.

3. Preparation of the geotouristic trail: the results gathered in the previous phases were consolidated and transformed into a geotouristic trail, with particular attention to the historical, architectonic, artistic, and geological aspects. The base used was the Plant of the SBSC, scale 1:300, prepared by the Secretariat of Urban Development of the João Pessoa Municipality, in which the area with the highest density of tombs with remarkable examples of these aspects was highlighted. Inside this area, four separate stretches, which we named "patches," were indicated as being suitable for individual visitation.

\section{Cemeterial Tourism and Geotourism}

When burials inside the churches were prohibited and openair cemeteries were created as specific places for people to bury their dead, they quickly became real art galleries, suitable to be visited and admired. Their tombs, in a peculiar way, reflected the society whose members created them (Vovelle 1993). As the Englishman J. C. Loudon said in 1834: "Churchyards and cemeteries are scenes not only calculated to improve the morals and the taste, and by their botanical riches to cultivate the intellect, but they serve as historical records ... The tomb has, in fact, been the great chronicler of taste throughout the world." (Loudon 1843 apud Jupp 2005, p. 36).

However, as time went by, they started to lose those charming characteristics and entered the second half of the twentieth century forgotten. In Brazil, the situation became even worse, as they have gone to be considered disreputable areas, in which marginalized members of society like drug addicts, hobos, and prostitutes mingle.

Aiming at the recovery of the historical and cultural importance of these places, some European countries invested in cemeterial tourism programs, creating in 2001 the Association of Significant Cemeteries in Europe (ASCE 2014), which today congregates over 150 cemeteries throughout the continent and British Islands. One of the pillars of this association's program is to consider cemeteries as a major cultural attraction. Based on that premise, it has created cultural travel plans, maps indicating the location of tombs of famous people, historical information about the cemetery, and other products, at the same time promoting the idea that cemeteries are part of the European identity and emphasizing the value of heritage education associated to cultural tourism. 
Despite having been recognized as a cultural element long ago, cemeteries have only started to be used as a source for geoscientific studies of the abiotic heritage in recent decades. Curiously, the precursor of the urban geotouristic activity, according to Hose (2000), seems to have been the cemetery of Rochdale, Lancashire, England, in 1881, whose visitors could admire 30 small rock pillars that told the history of the creation of the Earth as seen by Geology. Considering the fierce debate between this then infant science and the Creationists, which was quite an achievement by the geologists of that time, particularly by placing the pillars in a cemetery, where religious feelings tend to be exacerbated.

Cemeterial tourism with a geological approach has been growing in Brazil (Kuzmickas and Del Lama 2012, 2015; Liccardo and Grassi 2014; Rodrigues and Del Lama 2014; Ferreira et al. 2016), the characteristics and aesthetical value of rock materials used in tombs, associated to other approaches, attract many tourists and researchers to this new niche in the geotouristic palette of options.

\section{Cemetery of the Lord of the Good Sentence, Downtown João Pessoa, State of Paraíba}

SBSC is situated in the urban district of the Bishop's Island, adjacent to the perimeter of the Historic Center, with its main entrance located at Sebastião Oliveira Lima Street. It has been under the city's municipality's management since 1936, and opens daily from 7 a.m. to 6 p.m., with free entrance (Fig. 1).

Since Brazil was a Portuguese colony until 1822, and the Portuguese Crown always tried to seriously prevent its contact with other cultures, it is acceptable to admit that the habits in use in Brazil were similar to those in use in Portugal. For the latter, by Cabral and Feijó (1985, pp. 86) describe the following: "In the early 19th century in Portugal, both in the cities and in the rural areas, the dead were buried inside or around the parish churches". When there was no room for all of them inside the churches, only the rich were buried inside, while the majority of parishioners were buried in the forecourt, either in collective graves or in individual ones.
Fig. 1 a Paraíba state in context of South America. b Historic Center in context of João Pessoa City. $\mathbf{c}$ Location of the Boa Sentença Cemetery in relation to the perimeter of the Historic Center of João Pessoa City
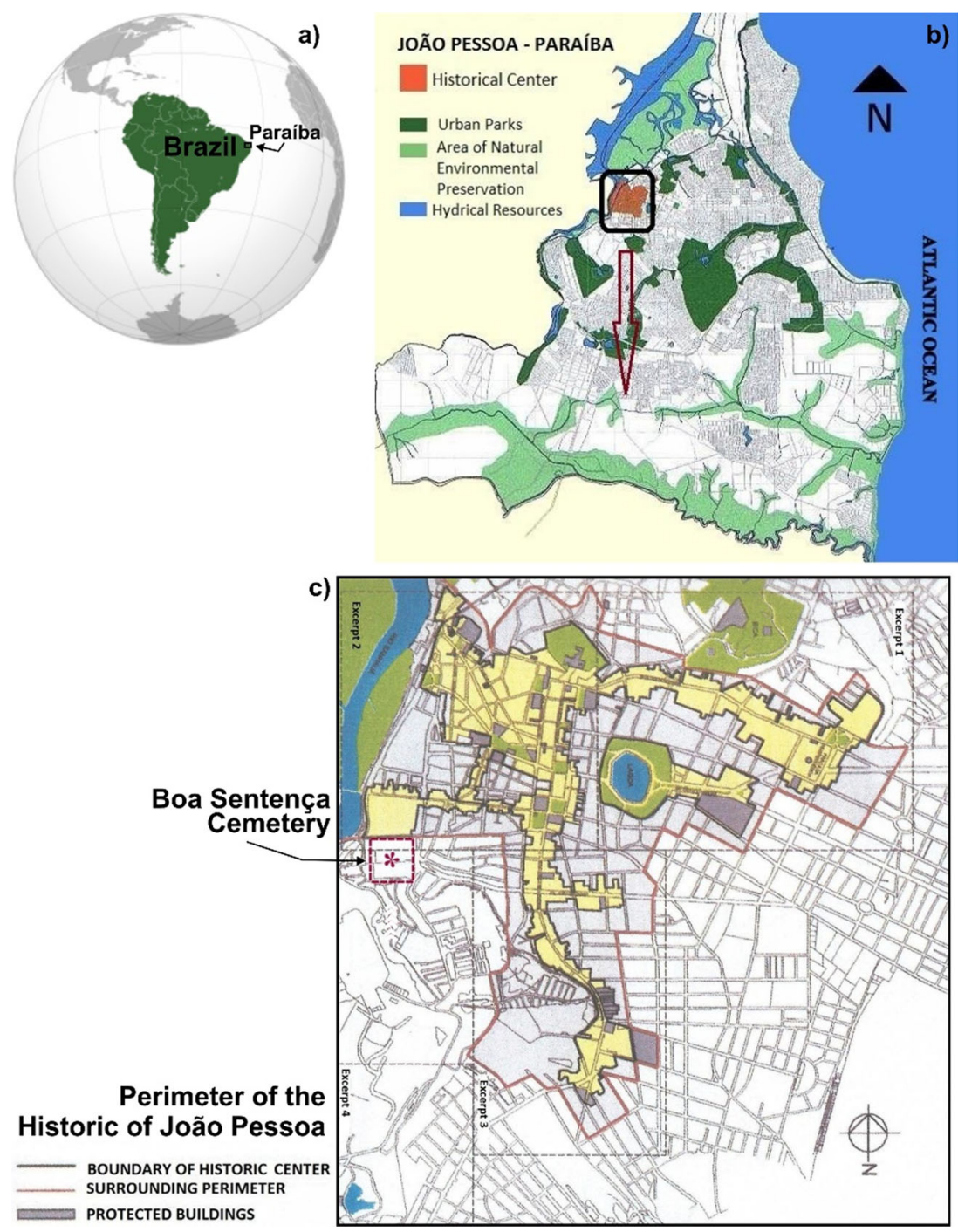


\section{Mapped Area}

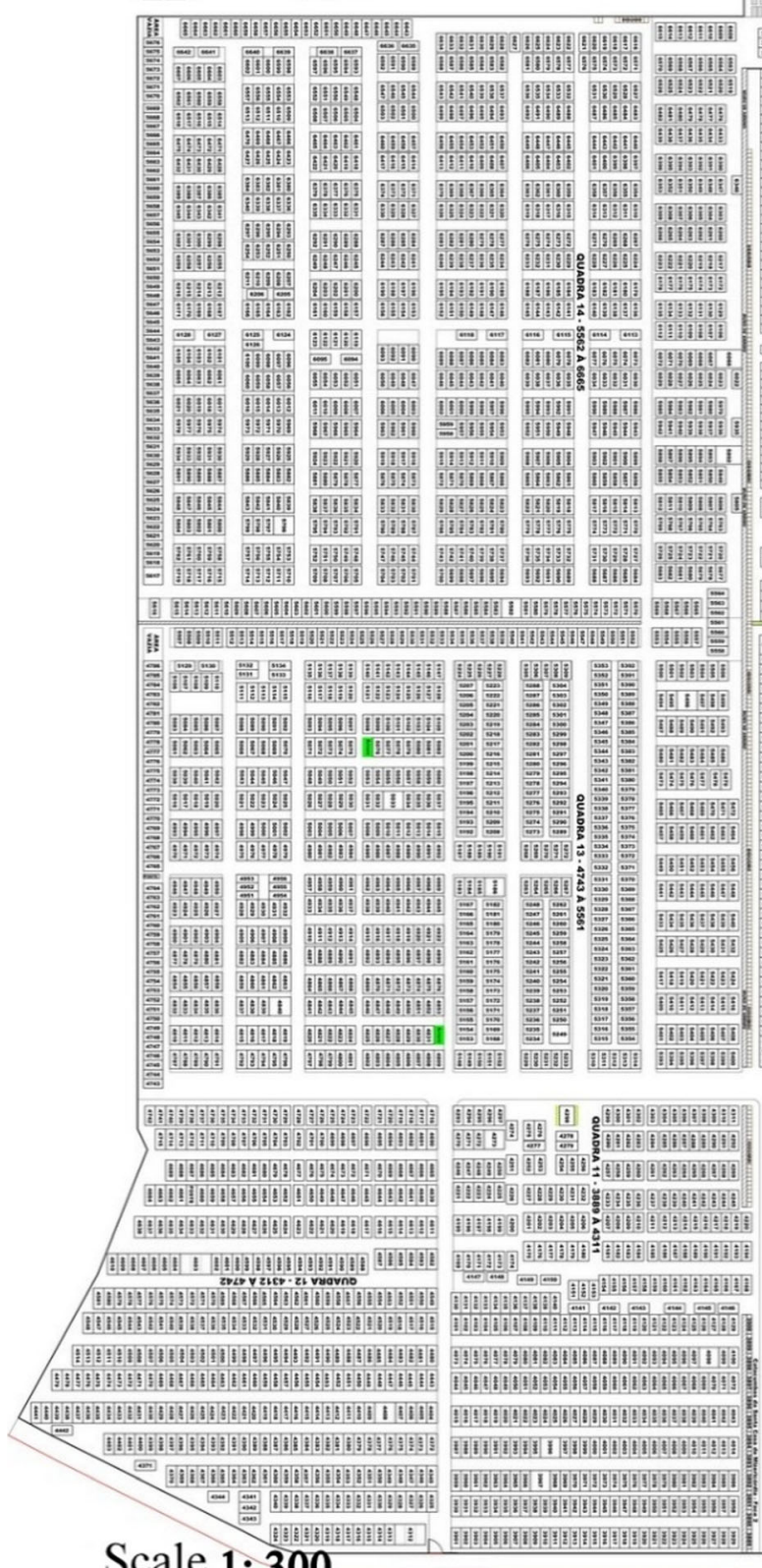

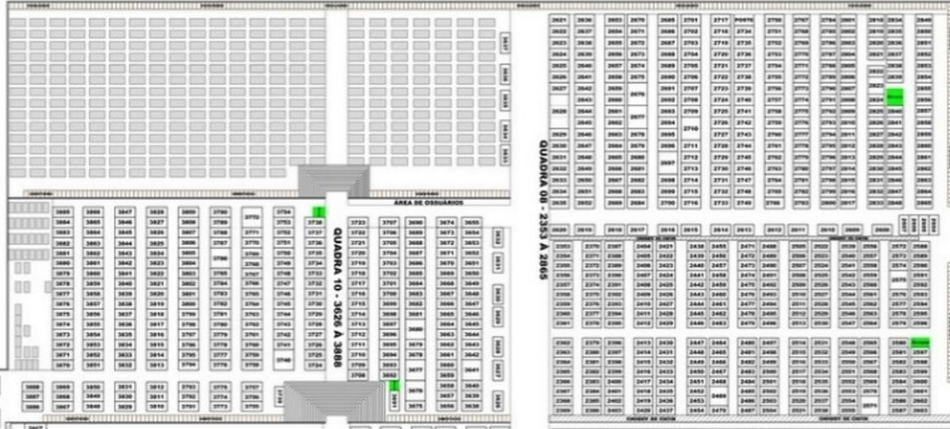

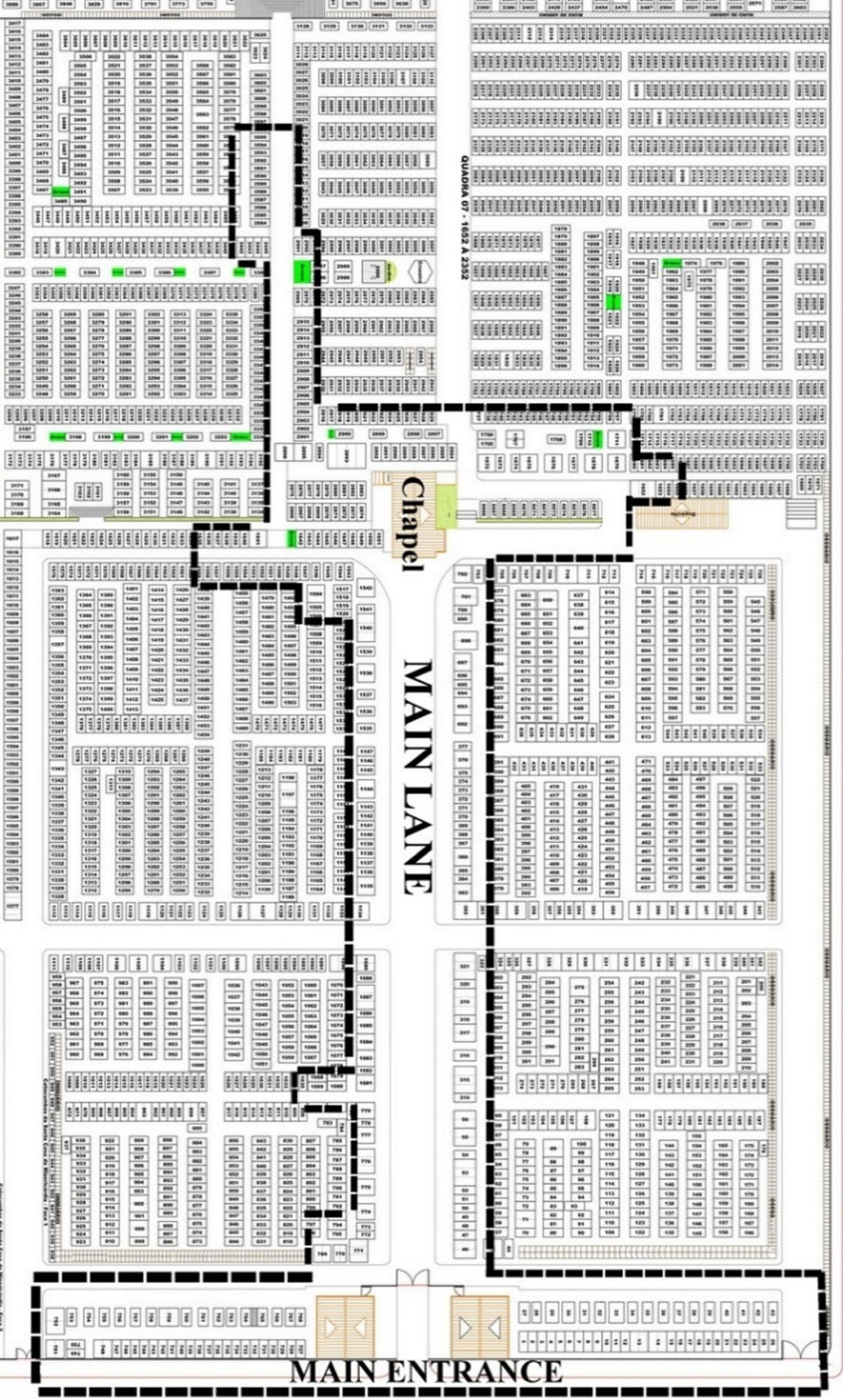

Fig. 2 Plant of the SBSC, showing the distribution of the tombs and the contour of the mapped area. Source: modified from SEDURB/PMJP (2016)

Until the early 1800s, then, burials in Brazilian cities and villages, and particularly for those people who had at least a minimal level of socio-economical standing, were, always that local conditions allowed, ad sanctus - a Latin expression, meaning, literally, close to the saint, and, in a broad sense, ideally inside a church (or, at least, if outside, very close to it).

The ill effects of such a practice had been noticed long before that time, and there were some complaints made public 


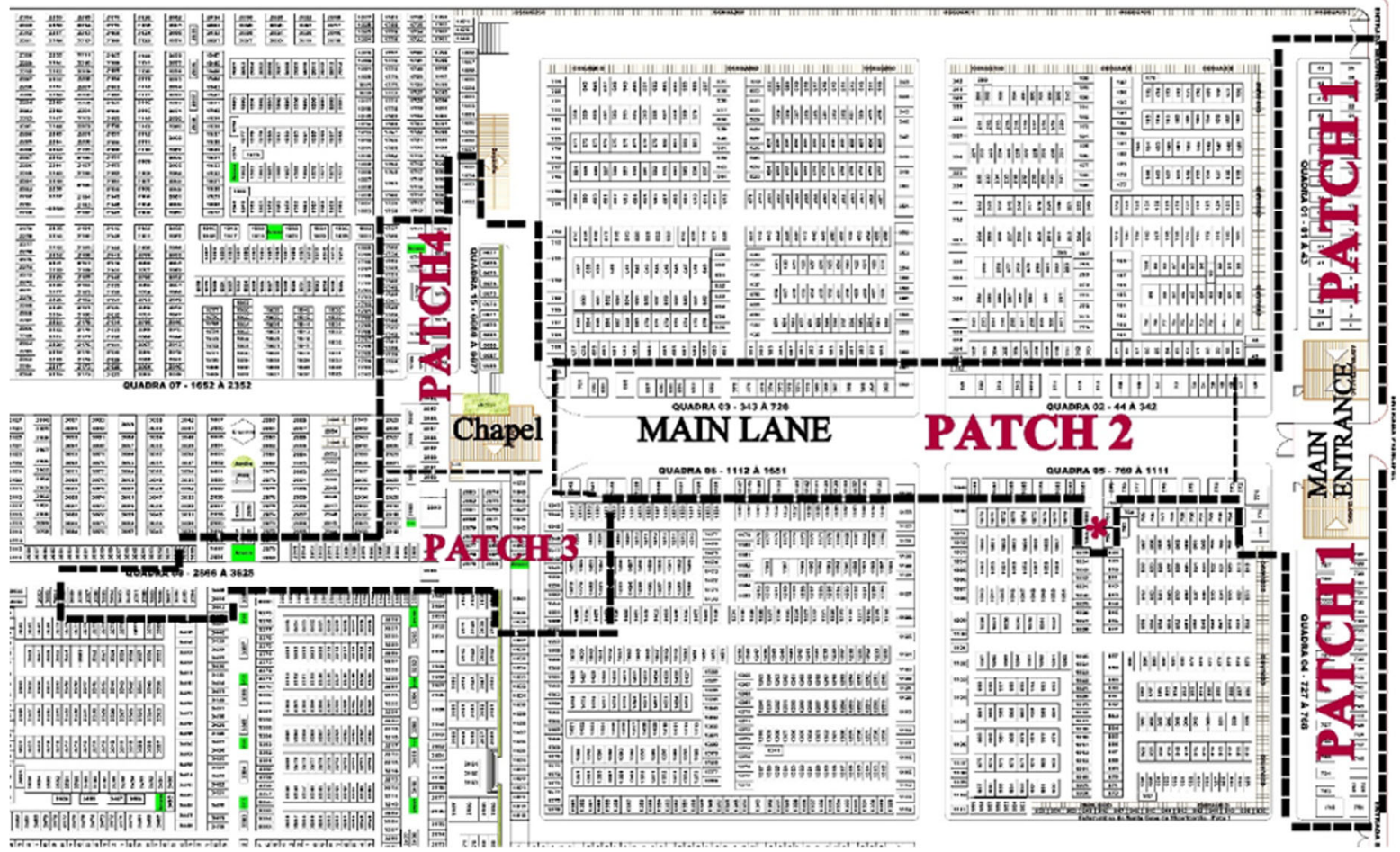

Fig. 3 Detail of the previous figure, with the area that was mapped divided into four patches, with the tombs existing in each of them. The green squares are gardens. North is to the top of the page. Source: modified from SEDURB/PMJP (2016)

at least since the early 1700 s, but only in the 1820 s, following the trend in Europe, the Imperial government recognized that such a practice was unsanitary, and decreed that cemeteries should be established outside the area of the churches. That movement was not easily accepted by a highly devout Catholic population, who feared that being buried far from the "spiritually safe" environment of the church would not guarantee them a blessed afterlife.

Partially as a result of that resistance, the first openair cemeteries in Brazil (with the exception of one in São Paulo, established in 1827 for a community of protestant German immigrants) were only established in the 1850 s.
In such a context, the SBSC was founded, in 1856, according to Aquino (1985), by the Holy House of Mercy, a Catholic institution omnipresent throughout the Portuguese colonial empire and still extant in many cities in Brazil. Before its opening, the only burial place in the city of João Pessoa was the forecourt of the church of the Holy House of Mercy, therefore an ad sanctus cemetery. This movement of the burial sites from the church to large open-air cemeteries, besides the sanitary aspect, can also be seen as part of a wider process of urbanization in which the cemeteries rose to a position of high importance in the physical aspect of the cities dreamed by the architects (Vovelle 1993), a movement which eventually led to the creation of very large urban cemeteries.
Fig. 4 Legend indicating the rock types used in the tombs. "Mixed" indicates a tomb where two or more rock types are used

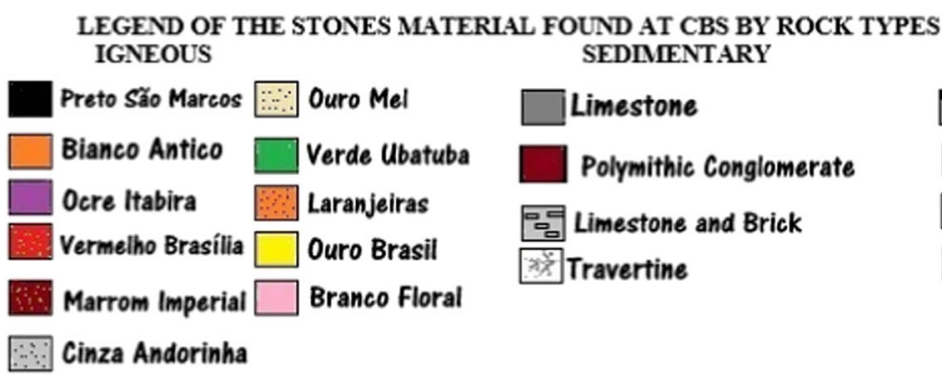

MIETAMORPHIC DCarrara Marble M. National Marble M. Pinta Verde Marble

Metaconglomerate Equador

Others $\square$ Architectural Detail

Mixed 


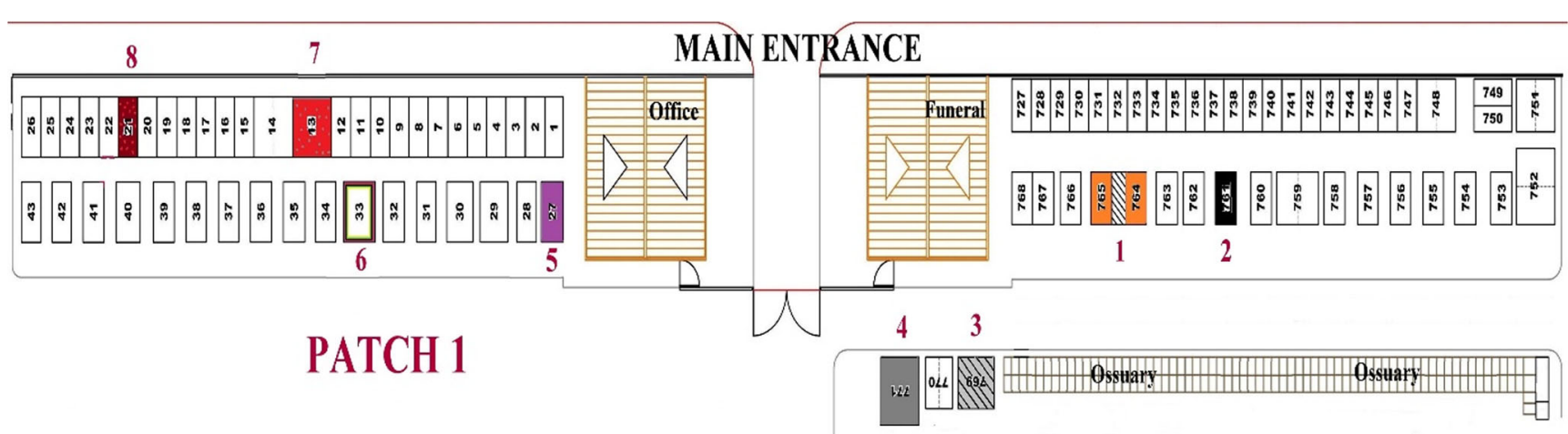

Fig. 5 Patch 1, with indication of the points (tombs) to be visited. North is to the left of the page. Source: modified from SEDURB/PMJP (2016)

The SBSC, then, is not only the first municipal cemetery in João Pessoa; it is also one of the first in Brazil. Nowadays, it holds 6.677 perpetual tombs and 385 temporary (rotative) tombs, plus hundreds of ossuary drawers (columbaria, for bones), occupying an almost square area covering $56.220 \mathrm{~m}^{2}$ (SEDURB/PMJP 2016; Fig. 2).

According to Azevedo (2008) in its first decades of existence, the SBSC had an area limited to a central lane, bordered by trees, going from the main entrance to the neighborhood of the now existing chapel. In fact, a line of limestone bricks at the curb of the central lane plus the existence therein of the oldest mausoleums corroborate that information. Various of these tombs, particularly those built before the 1950s, show the "PN-AM" (Pater Noster-Ave Maria) symbol, expressing the symbolic value of an immaterial element related to a Catholic creed that has been losing its power along the passage of time.

Later on, SBSC's growth went towards the part of the land plot behind the chapel, and still further on, to the sides. It is interesting to note that the population of the state capital, when the cemetery was founded, barely reached 9000 people (Rodrigues and Droulers 1981), versus an estimated population, in 2017 , of about 811,000 inhabitants (IBGE 2017).

Thinking from the point of view of the cultural heritage and geoheritage, the SBSC hosts three types of values that will be analyzed in an integrated way: historical value, scientific value (from a geological bias), and artistic/ architectonic value. It was based on these values that the area that was eventually mapped was selected, as well as the tombs to be analyzed, considering the rock materials utilized in the tombstones; the decorative elements present, like the stone carving and the architectonic details; and, when possible, the individual that was buried therein. The area selected was a portion of the cemetery in which the density of occurrence of such conditions was significant; as a final step, thinking about the logistics of the trail, this area was divided into four patches, as shown in Fig. 3.

A geotouristic trail plan is proposed in an area of the SBSC; the plan is divided into four patches, as indicated in Fig. 3. It includes a total of 42 tombs that have been selected and are recommended as points of visitation.

In the map of each patch, the rock type(s) used in each tomb is represented by a color, as per the following table (Fig. 4).

\section{General Description of the Four Patches}

Patch 1: it includes the two first lanes, respectively to the left and to the right, immediately adjacent to the main entrance (Fig. 5). Eight points have been

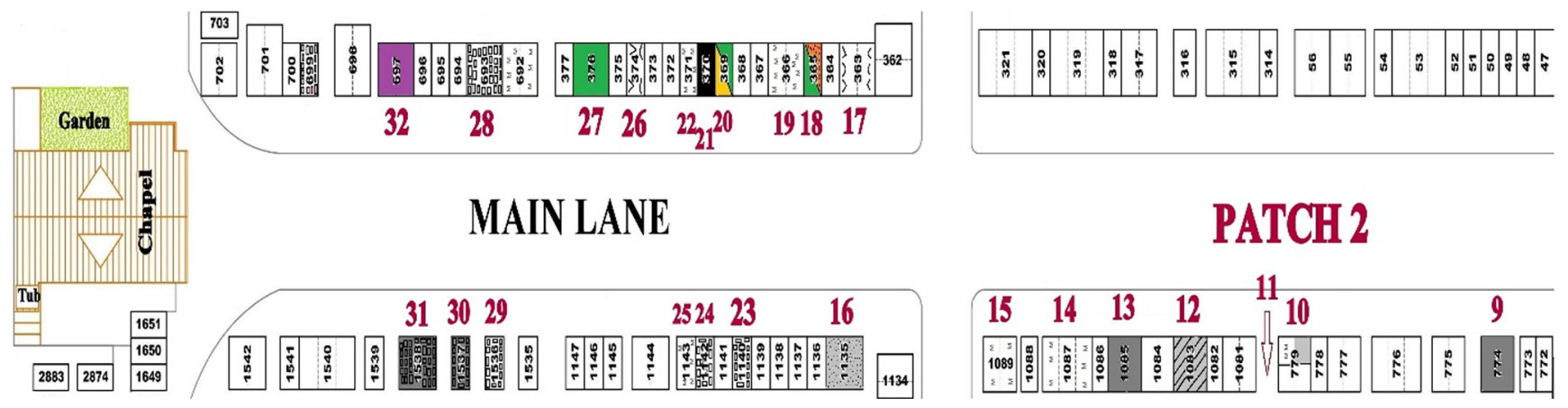

Fig. 6 Patch 2, with indication of the points (tombs) to be visited. North is to the top of the page 


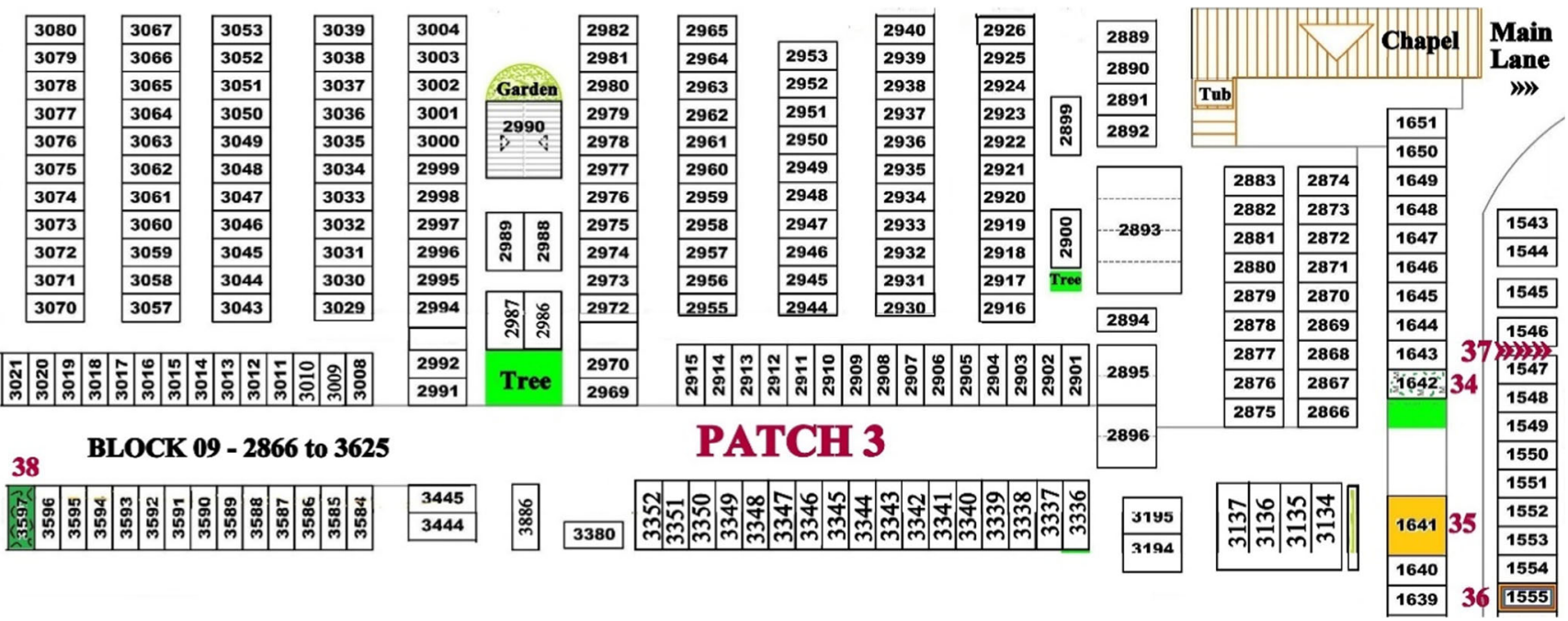

Fig. 7 Patch 3, with indication of the points (tombs) to be visited. North is to the top of the page

selected on this patch (numbers 1 to 8 ), which will be referred to in the text.

Patch 2: it corresponds to SBSC's main lane, from the main entrance to the chapel (Fig. 6). Along this lane are the oldest tombs, which are also those exhibiting the highest geodiversity ex situ; 25 points (tombs) have been selected (numbers 9 to 33), all of them referred to in the text below.
Patch 3: corresponding to the portion located south of the chapel, where five points (tombs) have been selected (34 38), as per Fig. 7; all of them referred to in the text below.

Patch 4: turning right at the end of the main lane, corresponding to the portion to the north of the chapel, where four points (tombs) have been selected (numbers 39-42), as per Fig. 8; these points are all referred to in the text below.

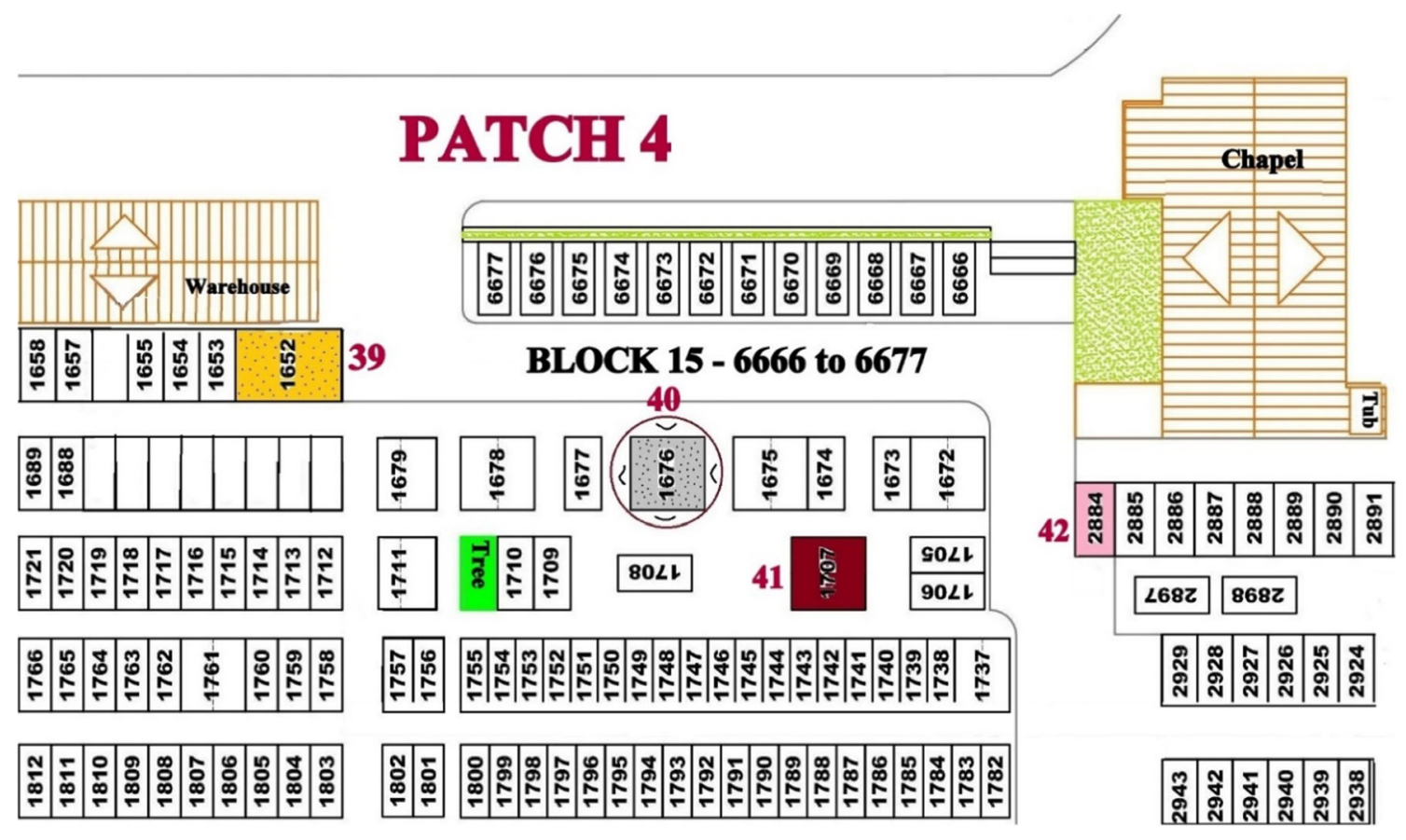

Fig. 8 Patch 4, with indication of the points (tombs) to be visited. North is to the top of the page 


\section{Stone Materials}

Rocks are among the main elements of geodiversity that can be intrinsically related to the human being and to culture. According to CPRM (2006, no page reference), geodiversity is defined as the

[...] abiotic nature (physical environment) consisting of a variety of geological environments, phenomena and processes that originate the landscapes, rocks, minerals, soils, water, fossils and other surface deposits that promote the development of life on Earth, having culture, aesthetics, economy, science, education and tourism as intrinsic values.

Thus, in a place where the tombs, their artistic details, the architectural styles, and the rocks present form a scenario that defines a particular cultural identity, the recognition of these stone materials and their characteristics become a cooperating tool in the analysis of the behavior of society during numerous time periods that can be diagonally studied through the combination of Cultural Heritage and Geoheritage.

Rocks of the three genetic types (igneous, sedimentary, and metamorphic) were found at SBSC, mainly in the form of ornamental stones polished in plaques, whose functionality is both esthetic and as a coating device. In some graves, more than one type of rock may have been used, including on those that show signs of restoration, with the stone material being replaced by a similar one. Of the three groups, the igneous rocks predominate (mainly granitoid rocks), followed by the metamorphic rocks (especially several types of marble and, in one tomb, metaconglomerate) and, to a lesser degree, sedimentary rocks (mainly limestones and, in one tomb, conglomerate).
However, most tombs were built with a material called "granilite," which corresponds to a mass of cement mixed with small pieces of limestone, quartz, and gravel, among other elements, which have low production costs.

Representing the metamorphic rocks, two types of marble were used on the graves of the main avenue, one imported and one national. The presence of Carrara marble, imported from Tuscany, Italy, symbolizes elegance and status, typical of a rising society, especially in the southeastern region, representing the Italian culture in funerary art (Liccardo 2010). At SBSC, it adorns a few mausoleums and tombs of important personalities or individuals with high purchasing power (Fig. 9a). The choice between the use of a national or imported rock, as well as the details in it, in the early twentieth century, clearly reflects the sociocultural nuances to which the society of João Pessoa, with its different social classes, was exposed in this historical context.

At SBSC, this type of marble presents a medium granoblastic texture $(0.2-1.5 \mathrm{~mm})$, with a soft grayish coloration with white veins, a solid structure, monomineralic (equigranular and hypidioblastic calcite, with an average size of $0.5 \mathrm{~mm}$, according to the analysis of a thin section), with stonework details (Fig. 9b). Normally, it easily erodes when exposed to the elements, especially to acid rains. The absence of this type of precipitation in João Pessoa kept this stone material relatively well preserved, as it is possible to see in point 3 of patch 1 , as well as in point 12 of patch 2 .

If the marble from Carrara is relatively rare, the national marble is abundant, both on graves dating from the first decades of the twentieth century and on present ones, represented by points $10,14,15,19,22$, and 25 (patch 2). It has an oriented structure, a consequence of the high concentration of calc-silicate minerals, particularly tremolite, which punctually can result in a greenish coloration. In this case, the marble is
Fig. 9 a Grave using marble imported from Carrara, Italy (section 3, patch 1). b Detail of the stonework in marble. Photos: Luciano S. Pereira (April 2016)

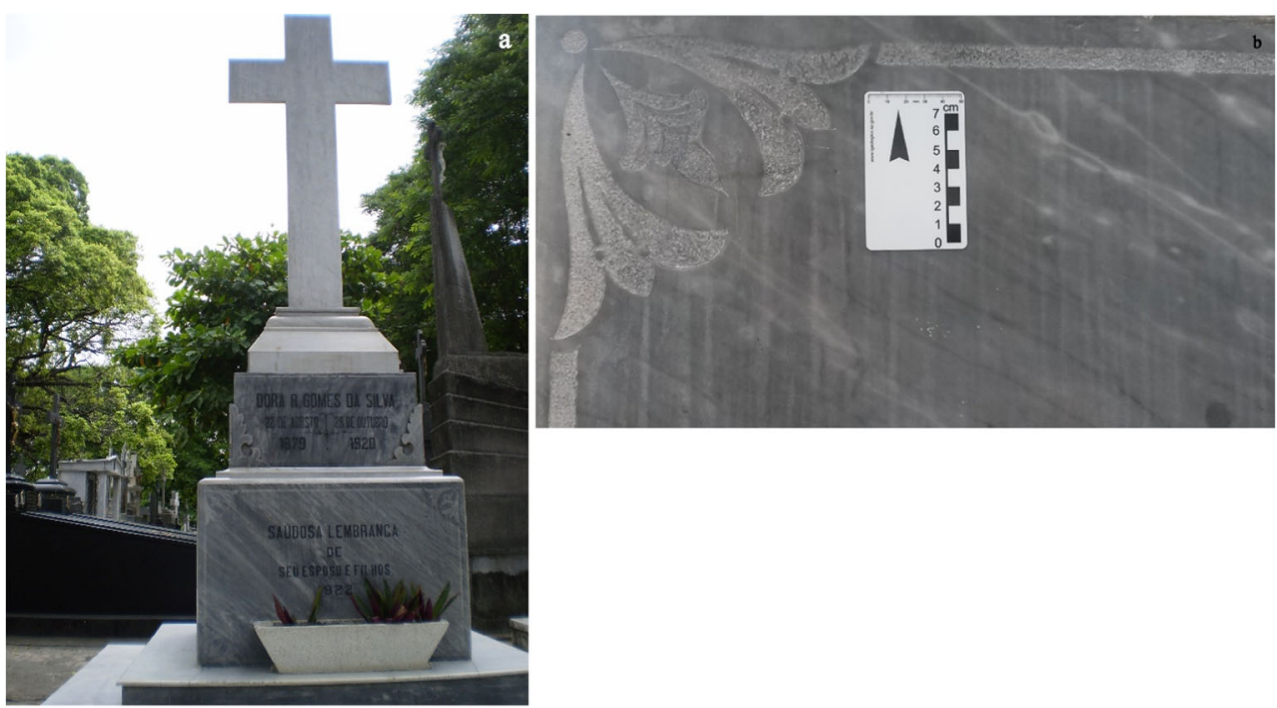


renamed "pinta verde" (green spot) (Fig. 10), as in point 34 of patch 3 .

In thin section, this marble displayed fine to medium granulometry, inequigranular, with mineral size varying between 0.5 and $2 \mathrm{~mm}$. Its main mineralogy is calcite $(80 \%)$, tremolite $(5 \%)$, talc $(3 \%)$, and quartz $(2 \%)$. Calcite appears in the form of equigranular and hypidioblastic crystals, varying from colorless to light brown, and reaching up to $2.2 \mathrm{~mm}$. The tremolite is colorless, with a large number of fractures and changes in its edge. It has a xenoblastic shape (Fig. 11), with crystals having an average size of $2 \mathrm{~mm}$ and in contact with the calcite. The talc, in turn, is colorless, with a xenoblastic texture and an average size of $0.8 \mathrm{~mm}$, occurring in contact with the tremolite and the calcite. The quartz occurs in small amounts and in the form of colorless grains distinguishable by their optical signal of positive uniaxial type.

A third type of metamorphic rock, found only in the tomb of João Gadelha and João Gadelha Filho (point 38 of patch 3), is represented by a polymitic metaconglomerate (Fig. 12), very similar to those found on the Ecuador Formation, from the Seridó Group, in the "paraibano" and "potiguar" Seridó. This metaconglomerate displays well-marked foliation, with a quartz matrix of medium granulometry and green color, as well as fragments of quartzite, schists, gneisses, and calcsilicates (with the presence of aligned epidote). The matrix consists of quartz, K-feldspar, plagioclase, biotite, and chlorite.

In the thin section, this metaconglomerate displayed medium to coarse granulometry, inequigranular, with mineral size varying between 1.5 and $3 \mathrm{~mm}$. The mineralogy found in the matrix is formed by quartz (45\%), muscovite (20\%), microcline $(20 \%)$, and plagioclase $(10 \%)$, apart from accessory phases such as titanite (3\%) and opaque minerals $(2 \%)$. The quartz occurs as xenoblastic crystals, with polygonal texture

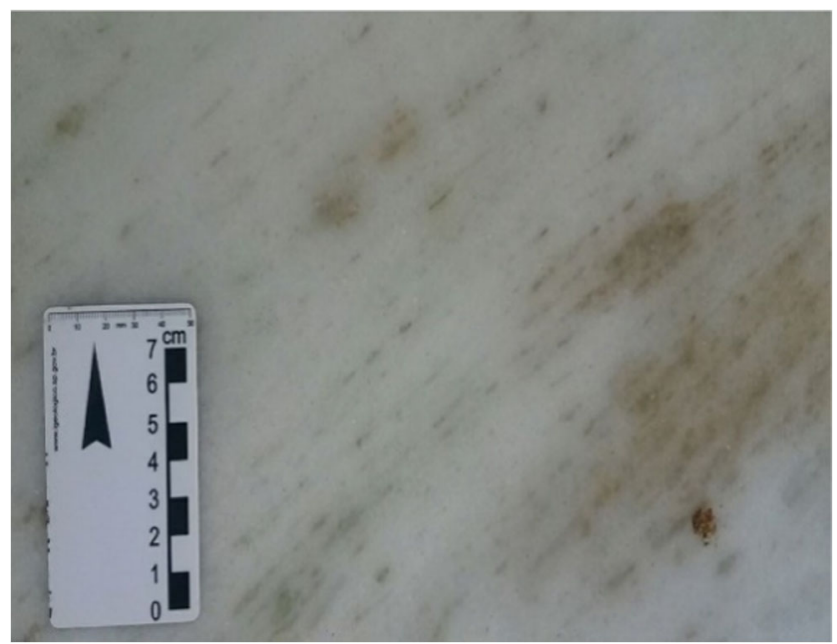

Fig. 10 Photo of the "green" marble, with the lamination and the tremolite concentrations. Photo: Luciano S. Pereira (April 2016)

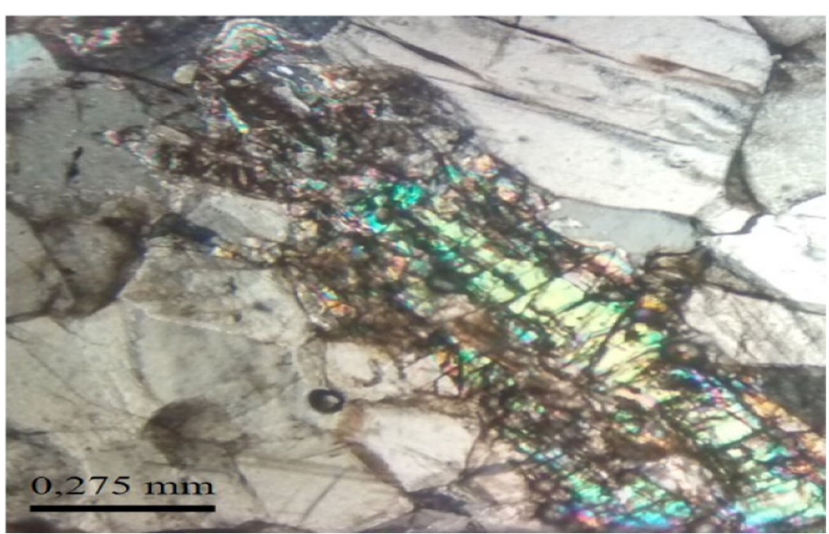

Fig. 11 Tremolite crystal included in calcite. Crossed nicols. Photo: Marcos Nascimento (July 2016)

or as ribbons of subordinate form. The muscovite presents itself as hypidioblastic crystals oriented according to the main foliation, and with contacts mostly rectilinear. The microcline occurs in the form of hypidioblastic crystals, sometimes as fenocristals. The transformation to muscovite is noted. The plagioclase presents itself with hypidioblastic crystals strongly modified to the epidote, the latter of greenish-brown color. Titanite and opaque minerals are included in the cited

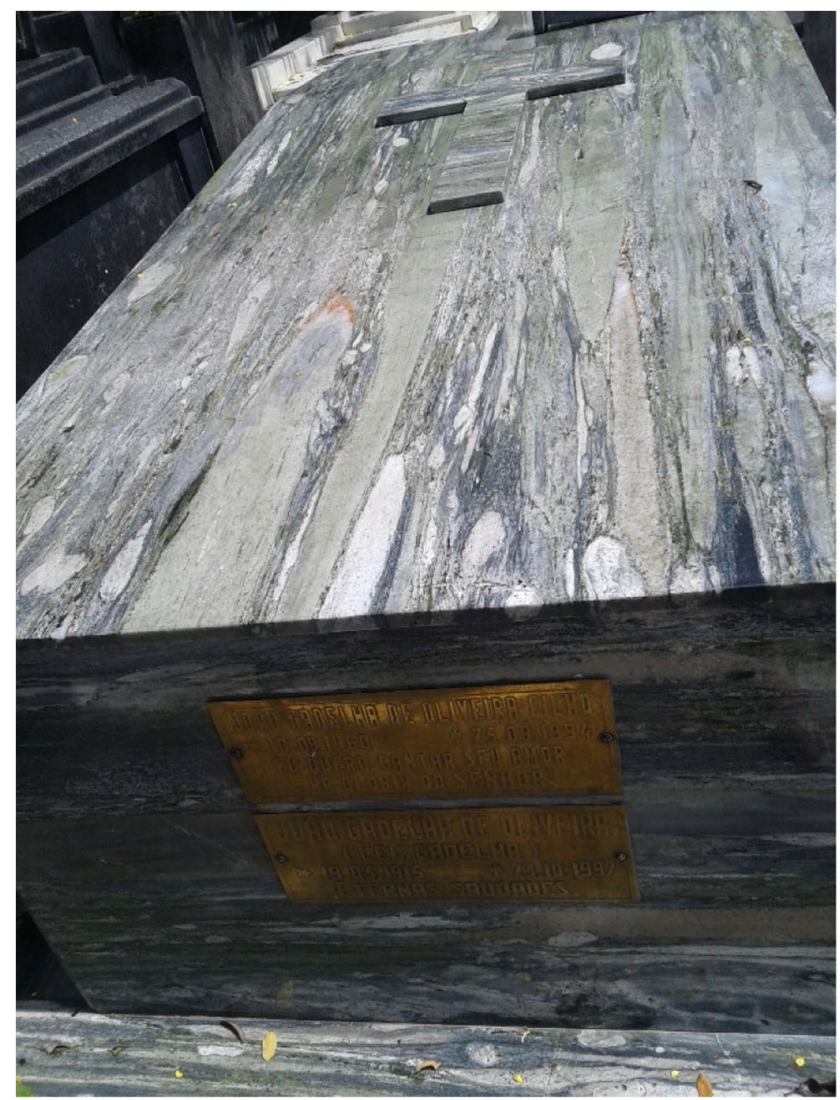

Fig. 12 Foliated metaconglomerate with rock fragments aligned. Photo: Luciano S. Pereira (April 2016) 
minerals. The presence of levels of calc-silicate enriched in quartz, calcite, epidote, microcline, plagioclase, and opaque minerals (Fig. 13) is common in this metaconglomerate. At these levels, it is usual to observe transformations of plagioclase in epidote and carbonate.

The igneous rocks, mostly represented by polished plaques and coming from Espírito Santo State, are the main type of rocks present at SBSC, basically on tombs dating from the post-1950s. Thirteen subtypes of granitoids and their respective commercial names were identified, and most of them were laminated for microscopic analysis. They are the Itabira Ochre Granite, the Brasilia Red Granite, the São Marcos Black Granite, the White Floral Granite, the Gray Andorinha Granite, the Ubatuba Green Granite, the Bianco Antico Granite, the Ouro Amêndoa Granite, the Ouro Mel Granite, the Laranjeiras Granite, the Cabaças Yellow Granite, the Imperial Brown Granite, and the Green Labrador Granite (Fig. 14). The Ouro Brasil Granite, although corresponding to an orthogneiss, will be described in this subchapter due to its already consolidated trade name. At least one specimen of each granite type was selected for the geotouristic itinerary.

The texture and mineralogical characteristics are summarized in Table 1. It is important to highlight that all the subtypes of granitoids found have a phaneritic and hypidiomorphic texture. In the latter case, the Gray "Andorinha" (Swallow) Granite presents itself as an exception, with its allotriomorphic texture.

Samples of sedimentary rocks are scarce, with the exception of limestone, relatively abundant on the tombs of the first decades of the constitution of the SBSC. It is important to report the existence of two specific tombs that present this type of rock with great esthetic beauty: Travertine type limestone and the polymitic conglomerate.

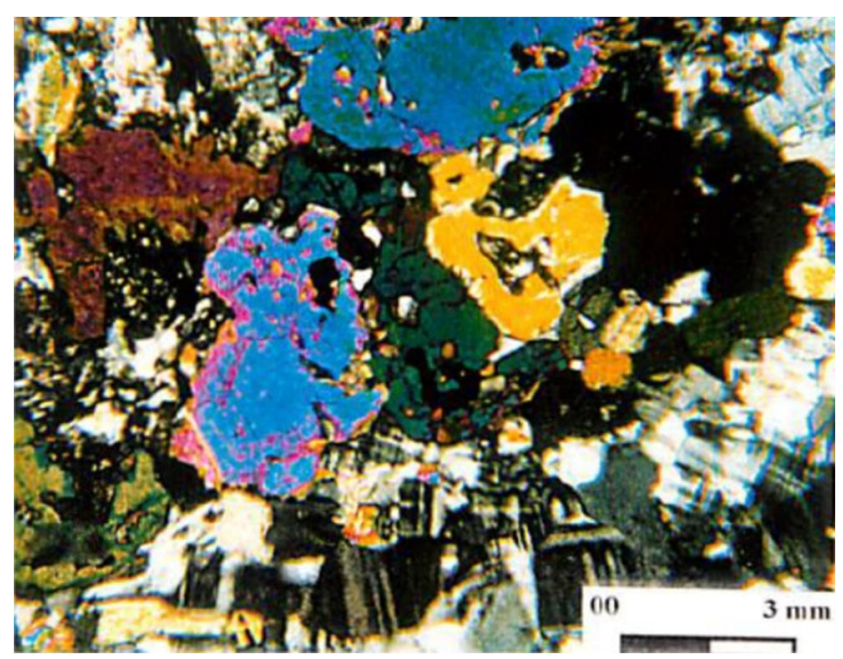

Fig. 13 Matrix of the metaconglomerate showing contact between a calcsilicate level (top of the photo) and a feldspar-quartz level (bottom of the photo). Photo: João Araújo (May 1998)
The oldest mausoleums are arranged along the main avenue, particularly on the south side, being essentially composed of limestone or marble. The oldest, dating from 1855, predates the foundation of the cemetery (point 4 , patch 1 ). It corresponds to a mausoleum built in stone masonry, with a limestone base plastered with cement and quicklime, embellished flowery, and an urn at the top. The upper part has a cast iron rail (Fig. 15a), with the decorated platband suggesting an eclectic style. Other tombs have similar structural features, such as points $13,23,24,28,29,30,31$, and 33 of patch 2 , whose masonry wall mixes massive blocks of limestone and brick, cemented with a mortar made of clay, sand, and quicklime (Fig. 15b, c).

Travertine type limestone, probably imported from Italy, was used on the tomb of Governor Tarcísio Burity (point 37 of patch 3 ), together with the national Marmoglass. In thin section, travertine limestone displays the predominantly micritic matrix, partly recrystallized mainly at the lamina edges, and the cement, when punctually observed, is characterized by a mosaic of fine irregularly arranged calcite grains.

It is also possible to note the presence of poorly selected siliciclastic grains of sub-angular to sub-rounded type. The quartz grains have dimensions varying between 0.25 and $0.50 \mathrm{~mm}$, being marked by their low birefringence and normal and wavy extinction. The feldspar grains, in a smaller amount, are characterized by the presence of tartan-type macles (Fig. 16a), thus being classified as alkaline feldspar fragments.

As for allochems, it is worth mentioning the wide presence of micritised bioclasts - peloids — of different sizes (varying from 0.5 to more than $1 \mathrm{~mm}$ ) and irregular shape (Fig. 16b), preferably arranged in the central parts of the thin section. It is also possible to observe the occurrence of areas with the presence of calcite clusters, in which the crystals of this mineral grow from the edge to the center.

Based on the characteristics described, it is possible to classify the rock as a limestone, which can be categorized as a pelmicrite, according to Folk's classification (1962), and as a wackstone, according to Dunham's classification (1962).

Marmoglass was made through a micro-crystallization process of glass crystals and marble powder, which results in a smooth, pore-free surface, milky white in color, and extremely resistant to products with any type of $\mathrm{pH}$.

The polymithic and polymodal conglomerate forms the tomb of Odilon Ribeiro Coutinho (point 41 of patch 4, Fig. 8). Massif, it has a reddish brown color, with a framework supported by subanged to subangular clasts of all kinds, which can reach 10 to $12 \mathrm{~cm}$. The clasts of andesite, sandstone, basalt, gneiss, pellets, and quartz grains, among others, are immersed in a very compact arcosean to sand matrix, rich in microgranular epidote and carbonates, with fine to medium 
Fig. 14 Main granite subtypes found in the cemetery. a Granite Ocre Itabira. b Granite Verde Labrador. c Granite Vermelho Brasília. d Granite Preto São

Marcos. e "Granite" Ouro Brasil. f Granite Branco Floral. g Granite Cinza Andorinha. h Granite Verde Ubatuba. i Granite Bianco Antico. j Granite Ouro Amêndoa. I Granite Ouro Mel. m Granite Laranjeiras. n Granite Amarelo Cabaças. o Granite Marrom Imperial. Photos: Luciano S. Pereira (May 2016)
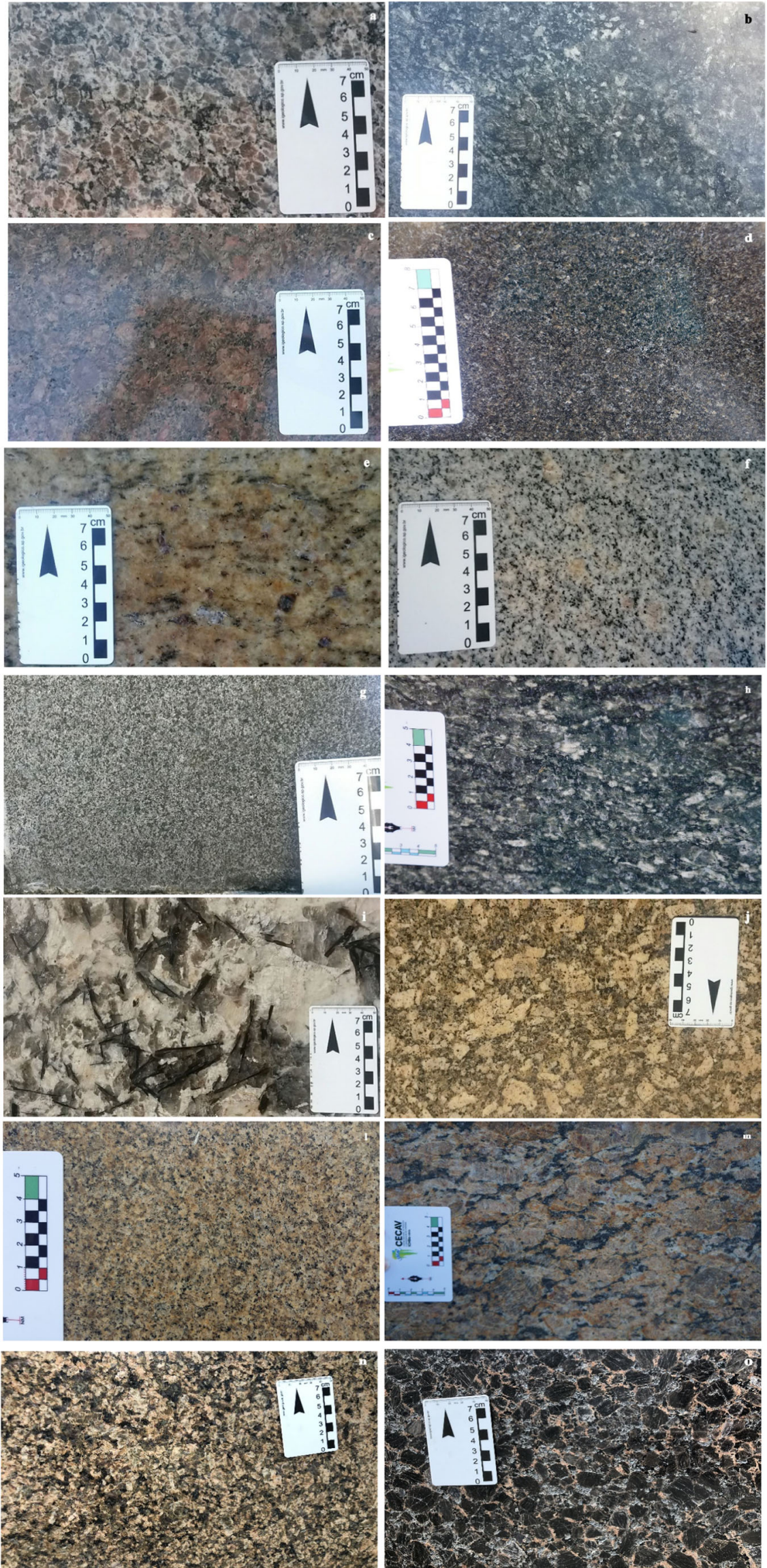


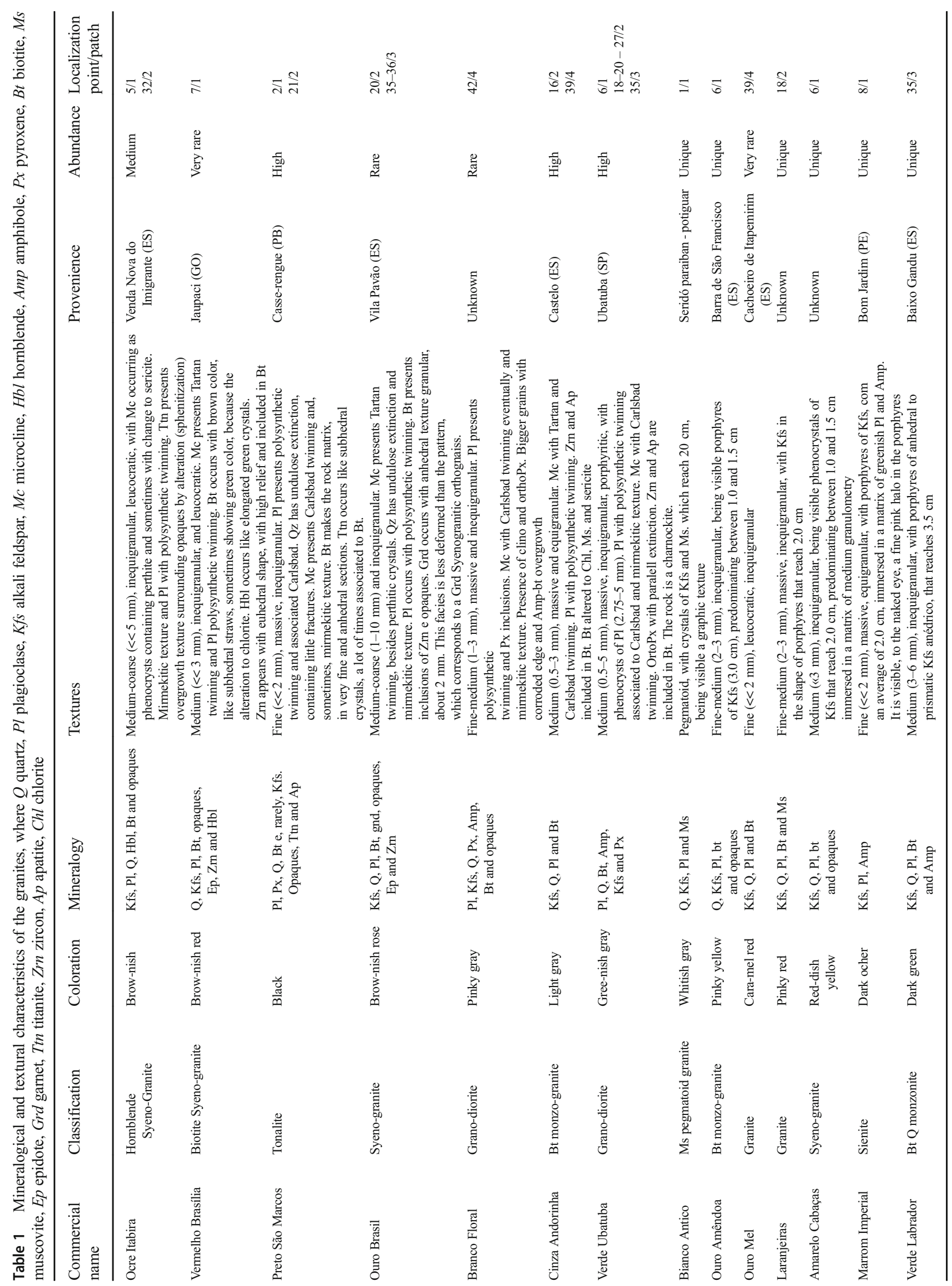


Fig. 15 Illustration of the oldest tombs, composed of blocks of limestones and brick, cemented by mortar. a Oldest tomb, dated 07.03.1855 (point 4, patch 2). b Mausoleums in the main lane, with similar structural pattern (points 29 to 31, patch 2). c Detail of the wall with an intercalation of limestone blocks and bricks cemented by mortar (point 29, patch 2). Photos: Luciano S. Pereira (April 2016)
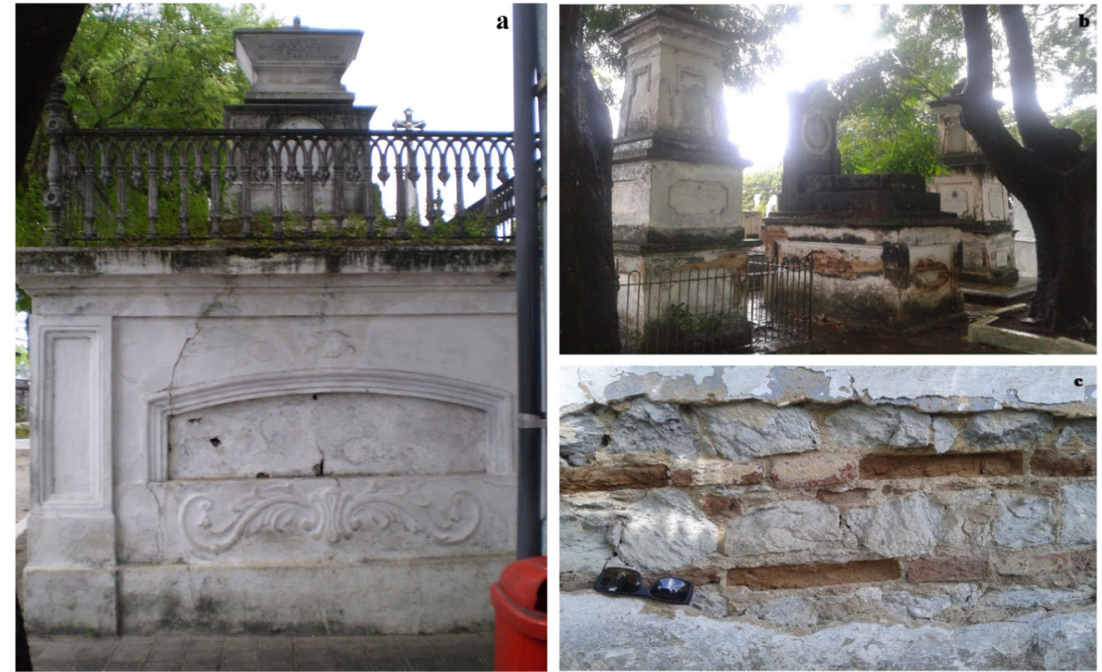

granulometry. The granulation of the crystals at the edges of the clasts evidences the occurrence of a ductile to brittleductile deformation, as well as the presence of a styolytic texture that generates serrated contacts and redirects and recrystallizes some crystals. In this matrix can be identified quartz, muscovite, and plagioclase crystals. Due to the textural and mineralogical characteristics, this conglomerate probably comes from the Jaibaras Basin, in Ceará, associated with the Aprazível Formation.

Microscopically it is shown as a heterogeneous and compact rock composed of millimeter to centimetric clasts, subangulous to sub-rounded or slightly ellipsoidal by deformation, with different types of minerals and rocks with a subordinate matrix/cementation rich in epidote, also containing carbonates. The clasts are of volcanic rocks with thin matrix and development of plagioclase with 0.5 to $2 \mathrm{~mm}$ in (Fig. 17a). It is also identified clasts of granitic composition with microcline + plagioclase + quartz + biotite. The cement is mainly composed of Microgranular epidote (Fig. 17b) having in some places formation of interstitial carbonate and iron hydroxide.

\section{Historical Value}

Several illustrious figures of the history of João Pessoa and Paraíba chose the cemetery as their last address, which denotes the historical value of SBSC. Some of these figures are politicians (governors, mayors, deputies and councilmen), painters, historians, writers, musicians, priests, scholars, among others that contributed for the local and regional history, and whose names, epitaphs, and dates are relevant historical data. This is one of the reasons that make the Père Lachaise Cemetery, for example, the fourth most visited place by tourists in Paris.

The frontal rail of the cemetery (Fig. 18a) is the same that limited the Public Garden, built in 1877-1878 in front of the Redemption Palace, at the end of the nineteenth century and that later, during the João Pessoa Government (1928-1930), was transformed into a square, named João Pessoa Square, already without the rail.

The date of the transfer to the cemetery is unknown. However, it is possible to observe that, in photos dating from 1908, the rail was still in the Square (Fig. 18b). The
Fig. 16 a Grains of K-feldspar with Tartan twinning and quartz with undulose extinction in micritic matrix. Crossed nicols. b Dark colorful micrited bioclasts (peloids). Paralell nicols. Photos: Marcos Nascimento (April 2016)
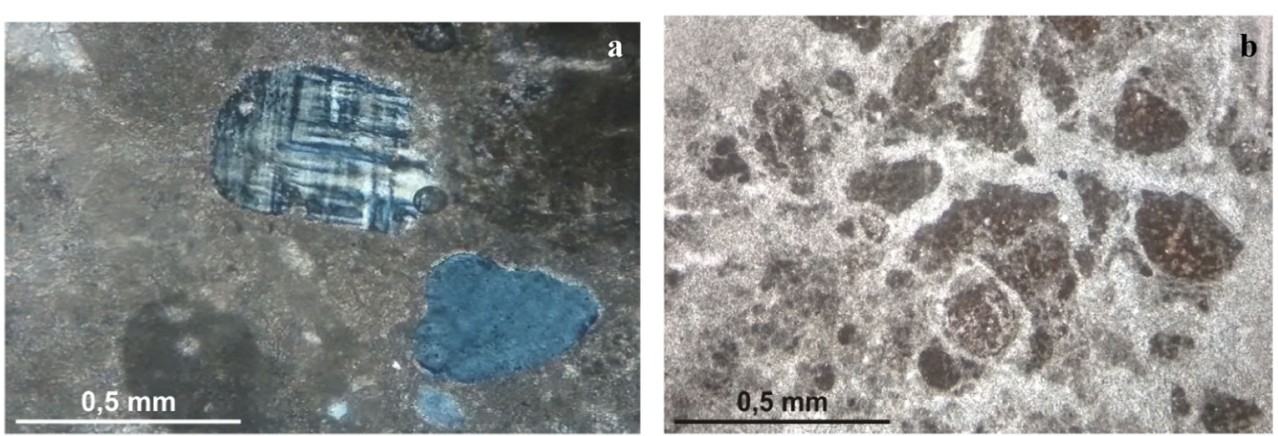


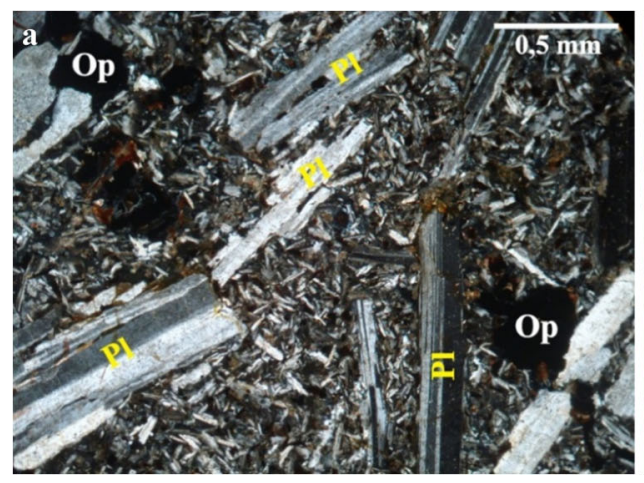

Fig. 17 a Part of a fine volcanic rock clast highlighting idiomorphic slats of plagioclase $(\mathrm{Pl})$ and opaque minerals $(\mathrm{Op})$ in a Microcrystalline matrix. Crossed nicols. b Submilimetric and millimetric clasts of quartz (Qz), Microcline (Mc), and opaque minerals $(\mathrm{Op})$, in a matrix/cementation with

IPHAEP - Institute of Historic and Artistic Heritage of the State of Paraíba-is about to recognize and preserve the rail, denoting the importance of SBSC as part of the cultural heritage of the city and highlighting its historical value.

\section{Artistic and Architectural Values}

The artistic value of SBSC is reflected on the tombs with beautiful sculptures, stonework details, and relevant architectural elements. Among them, it is possible to highlight the beautiful sculpture carved in national marble on the tomb of deputy Antônio Simeão Leal (point 11 of patch 2), who died in 1921 (Fig. 19a), displaying a sad-looking woman holding a garland of flowers. It is also worth mentioning point 7 of patch 1 (stonework in massive granite), point 9 of patch 2 (beautiful stonework in limestone), and point 10 of patch 2 (sculpture in national marble of an angel holding a cross, Fig. 19b).

The Jaime Seixas family tomb (point 26 of patch 2) displays a base in towed brick and a lid made of national marble, with the epitaph engraved in Carrara marble (Fig. 20a). The upper cross, also in Carrara marble, features a bouquet of flowers carved with refined artistic quality. The cast iron rail,

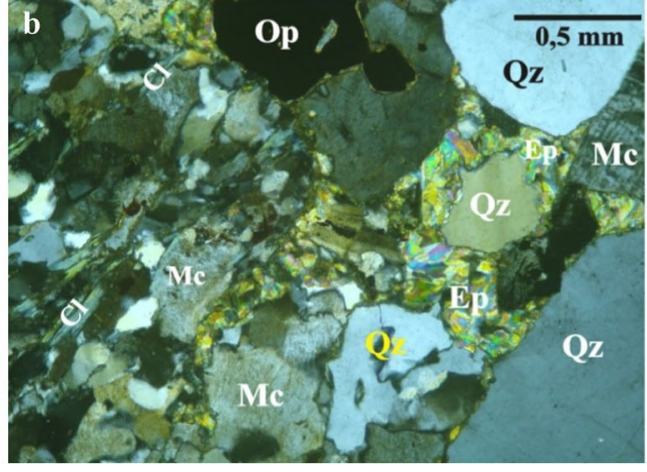

dominant epidote $(\mathrm{Ep})$. It is observed some chlorites $(\mathrm{Cl})$ with preferential orientation, also developed in the metamorphism. Crossed nicols crossed. Photos: Marcos Nascimento (April 2016)

molded into the masonry over the base mural, displays Art Nouveau elements, while the circles cut by straight lines with a flame-type tip belong to the Art Déco style.

The tomb of Clodomiro de Paula Basto (point 17 of patch 3 ), in a poor state of conservation, had its foundation built in towed brick and the base of the columns in granilite (Fig. 20b). It displays an eclectic architecture, with a decorated platband and balustrade, while the columns present a neoclassical style.

The only property listed by the IPHAEP, Decree no. 23808 of 2002, is the mausoleum of the interventor governor Antenor Navarro, who died in April 1932, referring to point 40 of patch 4. The monument (Fig. 21a), dated from 1945 and elaborated by sculptor Humberto Cozzo, is composed of a winged human figure in cast bronze, called "Fallen Angel" (Fig. 21b), placed on top of a triangular pedestal and stem in Cinza Andorinha Granite, with a height of about nine meters, on a rectangular masonry base.

The pedestal has a triangular shape with the point turned frontwards. The front was decorated with a "V" cut-out whose ends terminate at the upper lateral sides of the pedestal and the tip at the lower front side. On both sides, under the V, there are four layered and sequenced cut-outs. This layering is characteristic of the Art Déco style. The angel sculpture displays Art
Fig. 18 a Front grid of the cemetery, transferred from the Public Garden. b Photo 1908 of the Garden showing, on the right, the grid. Photos: a Luciano S. Pereira (April 2016); b Humberto Nóbrega collection (1908?)
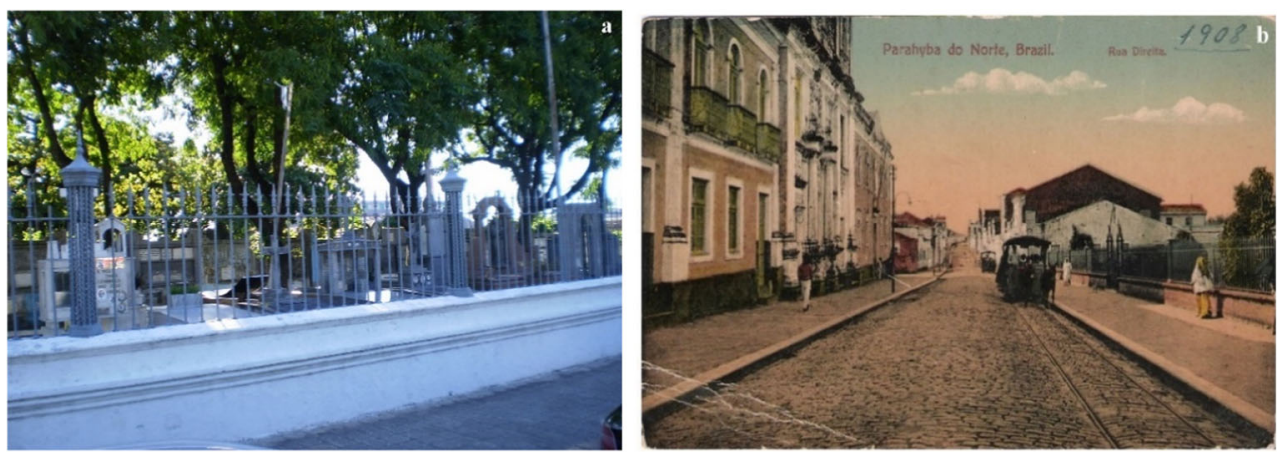
Fig. 19 Examples of sculptures in national marble. a Tomb of the deputy Simeon Leal (point 11 patch 2). b Gama and Melo family grave (point 10 patch 2). Photos: Luciano S. Pereira (April 2016)

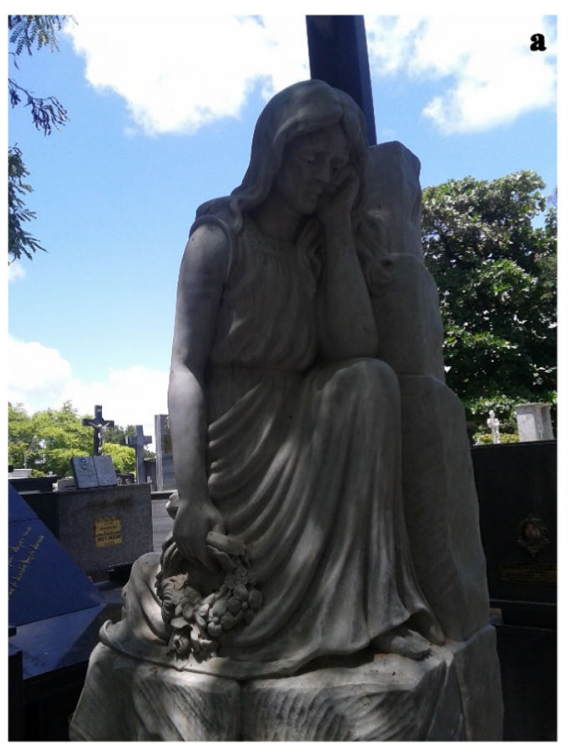

Déco characteristics, on the geometric and angular aspects of its body and upper part of the wings, and Art Nouveau characteristics, on the curved and asymmetrical lines used on the tips of the wings, which soften the formal angularity through this obvious organic conception.

\section{Final Considerations}

Cemeteries are reflections of the society to which they belong, carrying values linked to material and immaterial goods. Walking through the main avenue of the Senhor da Boa
Sentença Cemetery in João Pessoa, among century-old trees, surrounded by the oldest graves of the cemetery, stone materials are defined in combination with the artistic and architectural details that identify different social classes and specific time periods that allow the study of theories that permeate the Exact and Human Sciences as well as Geosciences.

The choice of the Senhor da Boa Sentença Cemetery to include in the itinerary as an area of geotourism interest is justified by the importance that the architectural elements and the rocks, with their artistic details, have as disseminators of geological knowledge and culture: it is the largest cemetery of the state; it is possible to make a temporal
Fig. 20 Tombs with different architectural details and finishing. a Art nouveau iron grade with art deco elements. Note the degree of refinement of the crucifix carved in Carrara marble. b Grave presenting neoclassical columns, although the style of the set presents characteristics of eclecticism. Photos: Luciano S. Pereira (April 2016)
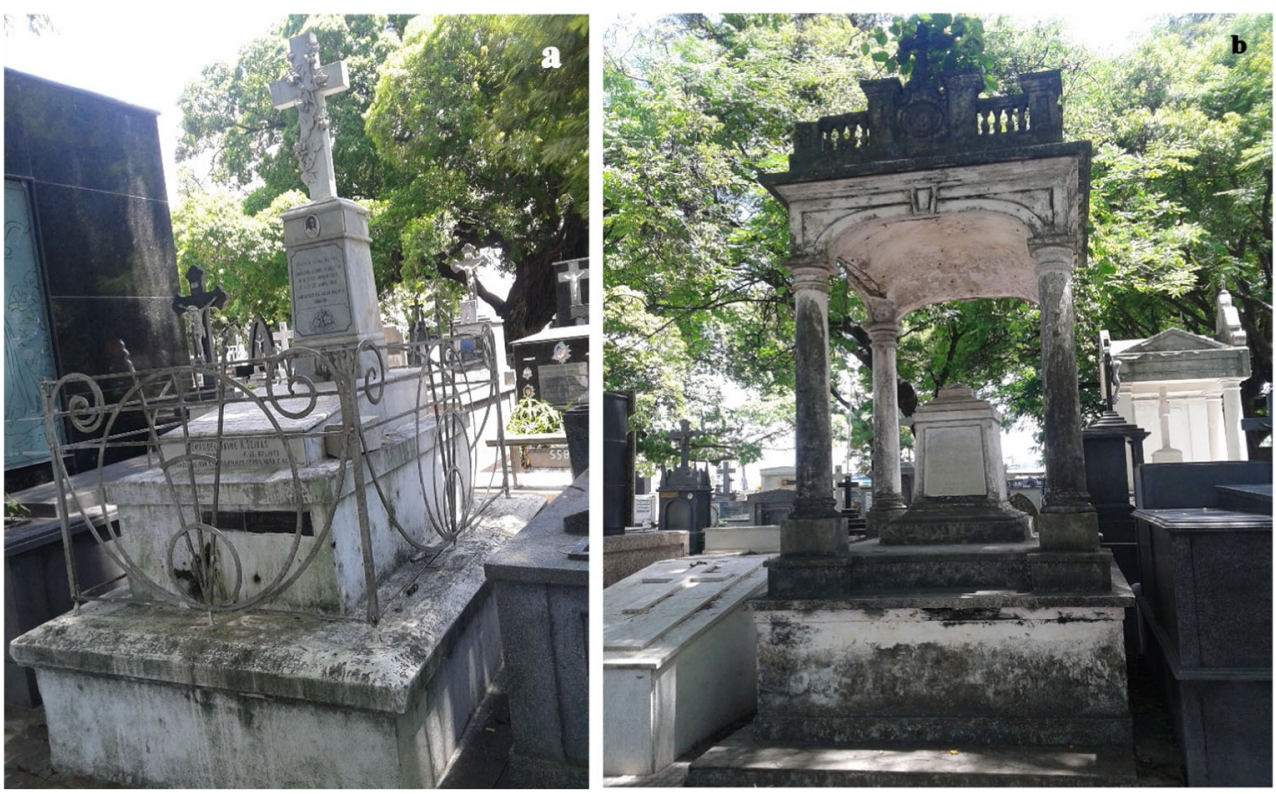
Fig. 21 a Mausoleum of Interventor Antenor Navarro, listed by IPHAEP. b Detail of the sculpture "Fallen Angel." Photos: Luciano S. Pereira (April 2016)
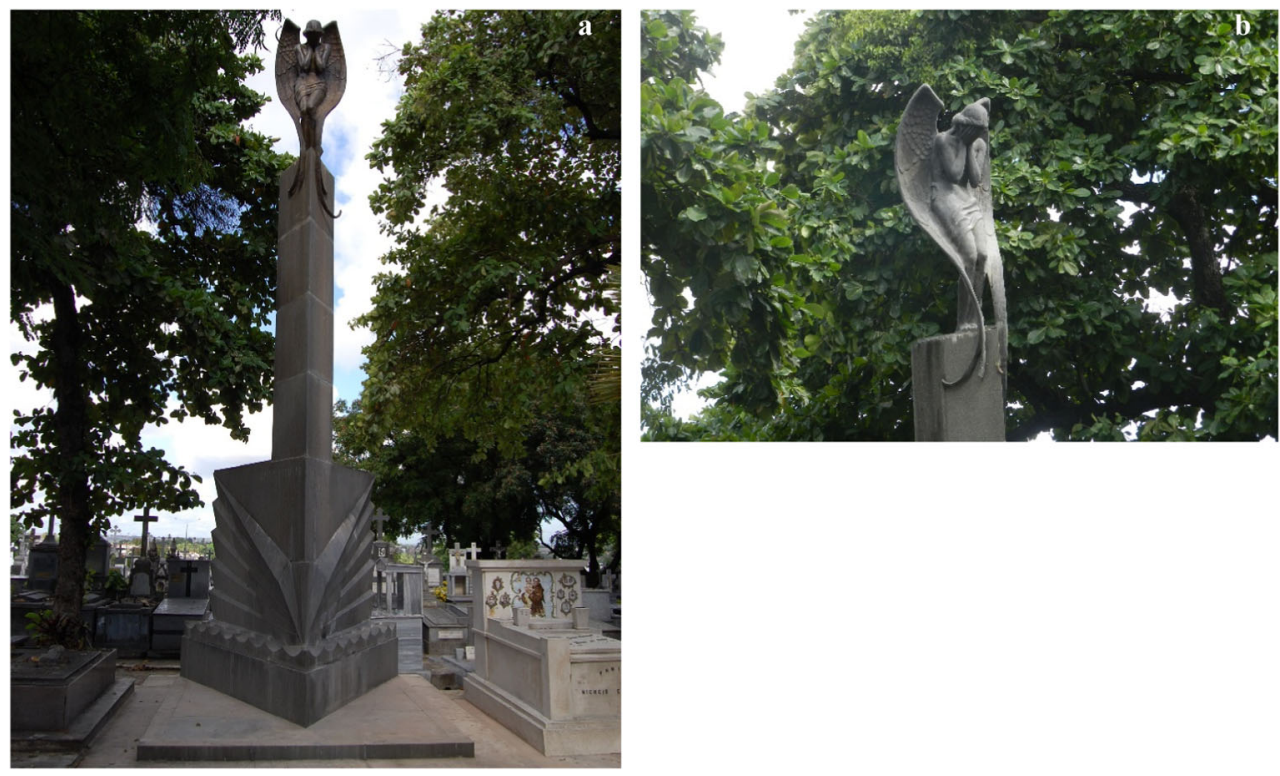

and social analysis from the geo-resources used in the tombstones; it is vulnerable to anthropogenic and natural action, requiring urgent measures of protection; it is part of the cultural heritage of the state and the recognition of the elements of geodiversity embedded in it is crucial when thinking about the context of Geoheritage. Thus, the funerary art, added to the geo-resources-geological value - used in the tombs, enhance the artistic value as a powerful tool for various purposes.

Founded in 1856, its first tombs used limestone or Carrara marble as preferential stone materials, with the predominance of the first over the second representing the social differences present in this nineteenth/early twentieth century society. Subsequently, national marble and granilite were added, two very common types associated with less wealthy classes. In the second half of the twentieth century, igneous rocks polished in plaques became the most appreciated for tomb decoration.

Thirteen types of ornamental rocks of intrusive igneous origin were identified, most coming from Espírito Santo State. Other identified and rare rocks in the cemetery are the polymictic conglomerate, orthogneiss, and the metaconglomerate. No extrusive igneous rocks were identified (except as fragments/clasts inserted in the conglomerate).

A combined analysis of the architecture, history, geology, and artistic details present in the SBSC tombs allows the maximization of a place merely used to house the dead into an additional geotouristic attraction to the adjacent João Pessoa Historic Centre, as well as a contribution for the comprehension of culture, history and geodiversity.

Funding information This research was supported by the Coordination for the Improvement of Higher Education Personnel (CAPES
Foundation- Process no. 11988-13/4), from which one of the authors is a fellow of full doctorate in Physical Geography from the University of Coimbra, Portugal.

\section{References}

Aquino AV (1985) Evolução e roteiro. In: Aguiar W, Mello J (eds) Uma Cidade de quatro séculos. Ed. Grafset, João Pessoa

Association of Significant Cemeteries in Europe - ASCE (2014) http:// www.significantcemeteries.org. Accessed 20 Nov 2017

Azevedo CA (2008) Arqueologia: estudos e pesquisas. Ideia, João Pessoa Cabral M, Feijó P (1985) A morte no Portugal Contemporâneo. Aproximações sociológicas, literárias e históricas. CPRM-Serviço Geológico do Brasil, Querco http://sigep.cprm.gov.br/. Accessed 10 July 2015

CPRM (2006) Mapa Geodiversidade do Brasil. Escala 1:2.500.000. Legenda expandida. Brasília: CPRM/ Serviço Geológico do Brasil, 2006, 68 p. http://www.cprm.gov.br/publique/media/ planeta_terra.pdf. Acessed 21 May 2015

Declaração de Arouca (2011) http://www.azoresgeopark.com/media/ docs/declaracao_de_arouca_geoturismo.pdf. Accessed 12 Sept 2016

Dunham RJ (1962) Classification of carbonate rocks according to their depositional texture. In Ham WE (ed) Classification of carbonate rocks. American Association of Petroleum Geologists Memoir, n. 1, p 128-141

Ferreira AC, Figueiredo MA, Rocha LC, Gomes I, Rosa DB, Nascimento LA (2016) Proposta para criação de roteiro geoturístico baseado na geodiversidade litológica, contexto histórico e sociocultural nos cemitérios de São João Del-Rei. Geonomos 24(2):264-269

Folk RL (1962) Spectral subdivision of limestone types, In: Ham WE (ed) Classification of carbonate rocks. American Association of Petroleum Geologists memoir, n. 1, pp 62-84

Hose TA (2000) European 'geotourism'- geological interpretation and conservation pro motion for tourists. In: Barettino D, Winbledom WA, Galego E (eds) Geological heritage: its conservation and management. ITGE, Madri, pp 127-146

Instituto Brasileiro de Geografia e Estatística-IBGE (2017) Recenseamentos gerais e estatísticas populacionais no Brasil. 
http://memoria.ibge.gov.br/sinteses-historicas/historicos-doscensos/censosdemograficos\#_ftn11. Accessed 13 April 2017

Instituto de Pesquisas Tecnológicas-IPT (1990) Catálogo das rochas ornamentais do Estado de São Paulo. Secretaria da Ciência, Tecnologia e Desenvolvimento Econômico. - SCTDE - PRÓMINERIO, São Paulo. Jupp P (205) From dust to ashes. Cremation and British Way to death. Palgrave McMillan, London

Kuzmickas L, Del Lama E A (2012) Utilização de métodos não destrutivos no estudo de estado de conservação dos jazigos pétreos do cemitério da Consolação, São Paulo. Cong. Bras. Geol., 46, 2012, Santos. Anais... Santos: SBG, Cd- rom

Kuzmickas L, Del Lama EA (2015) Roteiro geoturístico pelo cemitério da Consolação, São Paulo. Geociências 34(1):41-54

Liccardo A (2010) La Pietra e L'uomo: cantaria e entalhe em Curitiba. Beca- Ball Edições, São Paulo
Liccardo A, Grassi C (2014) Geodiversidade no Cemitério Municipal de Curitiba como elemento cultural em análises de patrimônio. Geonomos 22(1):48-57

Pereira LS, Amaral J (2014) Geoturismo urbano: análise da tipologia geológica e cultural da Capitania da Parahyba. Cad Est Pesq Tur 3:239-264

Rodrigues R P, Del Lama E A (2014) Comparação entre as formas de intemperismo presentes nos cemitérios São Paulo (SP, Brasil) e Pere- Lachaise (Paris- França). Cong. Bras. Geol., 47, 2014. Anais... Salvador: SBG, Cd- rom

Rodrigues J L, Droulers M (1981) João Pessoa: o crescimento de uma cidade. Fundação Casa de José Américo, João Pessoa

SEDURB/PMPJ (2016) Mapeamento do Cemitério Senhor da Boa Sentença. SEDURB, João Pessoa. Scale 1:300

Vovelle M (1993) L'heure du grand passage: chronique de la mort. Gallimard, Paris 